\title{
Bourges, Impasse de la Poissonnerie
}

$n^{\circ} 064578$

\section{Laurent Fournier}

\section{(2) OpenEdition}

Journals

Édition électronique

URL : http://journals.openedition.org/adlfi/13893

ISSN : 2114-0502

Éditeur

Ministère de la culture

Référence électronique

Laurent Fournier, «Bourges, Impasse de la Poissonnerie », ADLFI. Archéologie de la France-

Informations [En ligne], Centre, mis en ligne le 19 janvier 2015, consulté le 19 avril 2019. URL : http:// journals.openedition.org/adlfi/13893

Ce document a été généré automatiquement le 19 avril 2019

(C) Ministère de la Culture et de la Communication, CNRS 


\title{
Bourges, Impasse de la Poissonnerie
} $n^{\circ} 064578$

\author{
Laurent Fournier
}

Lien Atlas (MCC) :

http://atlas.patrimoines.culture.fr/atlas/trunk/index.php?

ap_theme=DOM_2.01.02\&ap_bbox=2.324;47.026;2.473;47.130

1 L'impasse de la Poissonnerie est située à proximité de la place Gordaine, en marge nordest de l'hyper-centre. La parcelle sondée au cours de cette intervention se situe à l'extérieur de la muraille du Bas-Empire, à proximité d'une des portes de cette fortification.

2 Deux sondages limités, du fait de la présence d'une dalle de béton, ont été pratiqués afin de déterminer la présence ou l'absence de vestiges archéologiques. Ces excavations ont été menées jusqu'à une profondeur de $4 \mathrm{~m}$ environ.

3 Au fond des deux sondages un remblai constitué d'une terre de couleur noire mêlée de fragments de tuiles, d'ossements et de quelques fragments de céramique gallo-romaine a pu être observé. Aucune structure n'était visible à cette profondeur. Les remblais supérieurs étaient constitués d'éléments de démolition, d'une couche de tuiles et d'un niveau de nodules de calcaire damé qui a été interprété comme le niveau de sol d'une cave dont un mur est visible en façade de la parcelle côté rue.

4 Compte tenu des contraintes imposées lors de la réalisation de cette opération, le potentiel archéologique de cette parcelle est difficile à déterminer. Des éléments céramiques du $\mathrm{I}^{\mathrm{er}} \mathrm{s}$. apr. J.-C. ont été découverts à une profondeur excédant 3,50 $\mathrm{m}$, mais aucune structure n'a pu être observée. 
INDEX

Index géographique : Centre, Cher (18), Bourges

Index chronologique : Gallo-romain

Mots-clés : céramique, tuile

operation Évaluation archéologique (EV) 